Original Paper http://ajol.info/index.php/ijbcs http://indexmedicus.afro.who.int

\title{
Semen characteristics and testicular biometry of Swiss albino mice treated with water soluble fractions of spent engine oil
}

\author{
S. O. BABALOLA ${ }^{1}$, O. S AJANI ${ }^{2 *}$ and A. A. ONI ${ }^{1}$ \\ ${ }^{1}$ Department of Zoology, Faculty of Science, University of Ibadan. \\ ${ }^{2}$ Department of Veterinary Surgery and Reproduction, Faculty of Veterinary Medicine, \\ University of Ibadan, Nigeria. \\ *Corresponding author; E-mail: drgoforth09@yahoo.com; drgoforth09@gmail.com; Tel: +2348038087625
}

\begin{abstract}
Contamination of soil and underlying groundwater with spent engine oil from automobile workshops and garages has serious ecological problems affecting plants and animals. The spermatotoxic potential of spent engine oil (SEO) was investigated using 24 adult male Swiss albino mice having mean weight of $24.67 \pm 0.2 \mathrm{~g}$ for 30 days. The mice were divided into 4 groups A, B, C, D of six mice each. Group A (control) was treated orally with distilled water, B (100\% water soluble fractions (WSF) of spent engine oil), C (10\% water soluble fractions (WSF) of spent engine oil) and D (1\% water soluble fractions (WSF) of spent engine oil). It was observed that the mean percentage sperm motility, viability and sperm count of the treated groups $\mathrm{B}, \mathrm{C}$, and D decreased compared to the control, although the differences were not significant ( $p>0.05)$. This same trend was observed for the morphologically abnormal sperm cells of mice in the treated groups compared to the control. It was concluded in this study that treatment with water soluble fractions of spent engine oil for 30 days had no negative effect on the semen characteristics and testicular biometry of Swiss albino mice.
\end{abstract}

(C) 2016 International Formulae Group. All rights reserved

Keywords: Mice, semen, spent engine oil, testes.

\section{INTRODUCTION}

Accidental or operational pollution by petroleum is a widespread and common problem wherever oil is produced, transported, stored, processed, or used at sea or on land (Orisakwe et al., 2004). This has been a major source of pollution especially in the Nigerian environment since the discovery, exploration and exploitation of crude-oil in Nigeria. After the petroleum refining processes, several products, mainly fuels and lubricating base oils, are obtained (VazquezDuhalt, 1989). Engine oil is one of the major refined constituents of the crude oil. It cleans, inhibits corrosion, improves sealing and cools the engine by carrying heat away from the moving parts as well aiding the easy starting of the engine (Olugoji and Ogunwole, 2008; Ekeh et al., 2010).

It is the lubricating engine oil that has given its service properties in a combustion engine, withdrawn from the meant area of application and considered unfit after its initial purpose that constitute ecological and environmental hazards to both plants and animals (Ekeh et al., 2010). This is often 
referred to as spent engine oil (SEO) or used mineral-base crankcase oil. It is a brown-toblack liquid produced when new engine oil is subjected to high temperatures and mechanical strain (ATSDR, 1997; Agarry and Ogunleye, 2012). Large amounts of used engine oil is released into the environment when the oil is changed and disposed into gutters, water drainages, open vacant plots and farmland, a common practice by automobile, and generator mechanics including allied artisans with workshops on the roadside and open places (Okonokhua et al., 2007; Kayode et al., 2009; Agbogidi and Eruotor, 2012).

This unethical and indiscriminate disposal of spent engine oil into the environment exposes both the flora and fauna to the toxic components of SEO. Water Soluble Fractions (WSF) of spent engine oil enter into aquatic environment as runoffs from rainfall and also migrates downward by gravity through the soil to water sources such as groundwater wells spreading laterally due to capillary forces and soil heterogeneity thereby polluting the water used for drinking and other domestic purposes (Ekeh et al., 2010; Chukwuma et al., 2012).

Used motor oil is a very dangerous polluting product (Vazquez-Duhalt, 1989). It contains a lot of toxic and carcinogenic substances that can cause detrimental effects on the ecosystem. There are relatively large amounts of aliphatic hydrocarbons, polychlorinated biphenyls, chlorodibenzofurans, lubrication additives and decomposition products in the used oil, including the highly toxic polycyclic aromatic hydrocarbons (ATSDR, 1997; Wang et al., 2000; Okonokhua et al., 2007). Considerable quantities of highly toxic heavy metals, such as $\mathrm{Pb}, \mathrm{Zn}, \mathrm{Cu}, \mathrm{Cr}$, $\mathrm{Ni}$ and $\mathrm{Cd}$, are contained in used crankcase oil (Vazquez-Duhalt, 1989). Other heavy metals such as $\mathrm{V}, \mathrm{Pb}, \mathrm{Al}, \mathrm{Ni}$ and $\mathrm{Fe}$, which were below detection in unused lubricating oil, have been reported to give high values (ppm) in used oil (Okonokhua et al., 2007; Patrick-Iwuanyanwu et al., 2009).
Different documented investigations show that these composite contents of SEO are toxic and therefore can damage various vital body organs such as the liver, kidney, heart, etc. in addition to causing disorders of the cardiovascular, haematopoietic, immune and nervous systems amongst others (Vasquez-Duhalt, 1989; Ochiogu et al., 2009; Patrick-Iwuanyanwu et. al., 2009; Ekeh et al., 2010; Arise et al., 2012). Chronic effects of naphthalene, an example of PAHs and a constituent of used engine oil include changes in the liver and harmful effects on the kidneys, heart, lungs and nervous system (Ekeh et al., 2010). Ingestion of these heavy metals, known to primarily accumulate in the liver, is also associated with the occurrence of various diseases (Jihen et al., 2008; Breton, 2013). Some of these metals are extremely toxic to the living system especially when they are found to exceed the regulatory limits. For example, Cadmium toxicity in kidney, heart, brain and liver has been reported (Nagano et al., 2000; Deveci and Deveci, 2011). Lead exposure in children and adults can cause a wide spectrum of health problems, ranging from convulsions, coma, renal failure, and death at the high end to subtle effects on metabolism and intelligence at the low end of exposures (European Commission, 2002; Hu, 2002).

Spent engine oil (SEO) may adversely affect the reproductive health of animals and humans (Ochiogu et al., 2009). Ssempebwa et al., (2004) reports antiestrogenic activities for crankcase oil, which suggested that its presence in the environment may be of concern for reproductive health. Testicular toxicity of Cadmium, a toxic heavy metal found in SEO has been reported (Nagano et al., 2000; Deveci and Deveci, 2011).

There have been various reports on the unethical disposal of spent engine oil in the environments (Patrick-Iwuanyanwu et al., 2009) and the consequent deleterious effect in humans and animals (Vasquez-Duhalt, 1989; Ochiogu et al., 2009; Ekeh et al., 2010; Arise et al., 2012); however, there is paucity of 
research reports on the effect of SEO on reproduction in animals. Therefore, this study was carried out to evaluate the changes in the semen characteristics and testicular biometry of Swiss albino mice caused by treatment with the water soluble fractions of spent engine oil.

\section{MATERIALS AND METHODS}

\section{Experimental animals}

Twenty-four male albino mice with average weight $24.67 \pm 0.2 \mathrm{~g}$ were obtained from the Animal House of Ladoke Akintola University of Technology Teaching Hospital, Osogbo. The mice were kept in clean and well ventilated cages in the Animal House of the Department of Zoology, University of Ibadan, Nigeria. They were fed with growers mash feed from Ladokun Feedmill, Ibadan and given water ad libitum. The care and manipulations of the animals were done in accordance with the Animal Practice requirements of the Animal Ethics Procedures and Guidelines and approved by the Animal Care and Use Ethics Committee of the University of Ibadan, Nigeria.

\section{Collection of spent engine oil}

Two litres each of two samples of spent engine oil were obtained from the automobile mechanic village at Ashi-Bodija, Ibadan. They were mixed together in a ratio of $1: 1$ before the commencement of the experiment.

\section{Preparation and preservation of the water soluble fraction (WSF)}

Equal proportion $(1: 1)$ of the two samples of spent engine oil (two litres each) was prepared and mixed together. The watersoluble fraction (WSF) was then prepared according to the method described by PatrickIwuanyanwu et al. (2009) with slight modifications. A measured volume of $150 \mathrm{ml}$ of the spent engine oil was slowly mixed with distilled water $(450 \mathrm{ml})$ in a $1000 \mathrm{ml}$ conical flask. The flask was covered with an aluminum foil and held tightly with a rubber band. It was then fastened to an electric stirrer (Corning Laboratory Stirrer [Lot NO:
06513503]), and shaken for 24 hours at 350 $\mathrm{rpm}$. Then, the mixture was left standing for another 24 hours to obtain a clear phase separation between the oil and water. The mixture was then poured into a separating funnel (with glass stopper), shaken vigorously for 2 minutes so that a clear separation between the oil and water can be obtained. It was then allowed to settle for another 5 minutes so that most of the oil droplets in the mixture had settled in the upper layer, the pure and clear WSF being obtained at the lower part of the funnel. The WSF was thereafter siphoned into a dark-colored, screw-capped Winchester bottle, and stored in a refrigerator $\left(0-4{ }^{\circ} \mathrm{C}\right)$ until required for use.

\section{Preparation of different concentrations of WSF of spent engine oil}

Three (3) different concentrations of WSF of spent engine oil were prepared; $1 \%$, $10 \%$ and $100 \%$. The $100 \%$ of WSF of SEO was prepared directly from the stock solution without dilution. $10 \%$ of WSF was prepared by measuring $10 \mathrm{ml}$ of WSF in a measuring cylinder and it was made up to $100 \mathrm{ml}$ by dilution with distilled water. $1 \%$ of WSF was prepared by measuring $1 \mathrm{ml}$ of WSF in a measuring cylinder and it was made up to 100 $\mathrm{ml}$ by dilution with distilled water.

\section{Experimental design}

The twenty-four animals were subdivided into four groups (A, B, C, and D) of six animals per group. The animals were allowed to acclimatize for two weeks before treatment commences. The mice were exposed to the treatments for 30 days and were individually weighed at day 0 and day 30 respectively.

Group A was used as control for all the groups and was provided daily with feed and distilled water only. Group B mice were daily given oral gavage of $0.2 \mathrm{ml}$ of $100 \%$ of WSF of spent engine oil individually with distilled water and feed. Group $\mathrm{C}$ mice were daily given oral gavage of $0.2 \mathrm{ml}$ of $10 \%$ of WSF of spent engine oil individually with distilled 
water and feed. Group D mice were daily given oral gavage of $0.2 \mathrm{ml}$ of $1 \%$ of WSF of spent engine oil individually with distilled water and feed.

\section{Sample collection and analysis}

Semen samples were collected from the mice 30 days post-treatment. The mice were anaesthetized with chloroform before sacrifice, the mid caudoventral abdominal incision was made with sterilized scissors, permitting instant access to the testis once pushed upward from the scrotum. The testes were then separated from the epididymis. The right and left epididymis were trimmed off the body of the testes and semen sample was collected from the tail of the epididymis through an incision made with a scalpel blade. The semen was dropped on warm glass slide and stained using warm Wells and Awa stains for morphological studies and staining for live/dead ratio was done using Eosin-Nigrosin stain. Also, percentage motility was carried out using 2 to 3 drops of $2.9 \%$ warm buffered sodium citrate kept at body temperature as described by Zemjanis (1970).

\section{Percentage viability}

This was done by staining one drop of semen and one drop of warm Eosin-Nigrosin stain on a warm slide. A thin smear was then made of mixture of semen and stain. The smear was air dried and observed under the microscope. The ratio of the in vitro dead sperm cells was observed and it is based upon the principle of Eosin penetrating and staining the dead autolysing sperm cells whereas viable sperm repel the stain (Zemjanis, 1970).

\section{Percentage motility}

It was evaluated with a drop of semen with drop of $2.9 \%$ buffered sodium citrate on a warm glass slide covered with a glass slip and viewed at a magnification of $\times 40$. Only sperm cells moving in a unidirectional motion were included in the motility count, while sperm cells moving in circles, in backward direction or pendulating movement were excluded (Zemjanis, 1970).

\section{Data analysis}

The data generated was analyzed using one way analysis of variance (ANOVA). SPSS Version 15 for Windows (SPSS Inc, 2006) and Microsoft Excel Professional Plus (Microsoft Corporation, 2010) were used to carry out all procedures.

\section{RESULTS}

\section{Semen characteristics of Swiss albino mice} There were no significant changes ( $>0.05)$ in the mean percentage motility, livability and sperm count obtained across the groups. However, the mean values of the sperm parameters obtained in the treatment groups $\mathrm{B}, \mathrm{C}$, and $\mathrm{D}$ were lower than the control although the values were within normal range for potential fertility. This indicates that a further increase in the duration of treatment might cause a negative effect by further reduction in the semen characteristics (Table 1).

\section{Spermatozoa morphology of Swiss albino mice}

The total percentage of abnormal sperm cells obtained across the groups were not significant $\quad(p>0.05), \quad$ although the abnormalities increased in the treatment groups compared to the control but the changes were not significant $(\mathrm{p}>0.05)$ (Table 2).

\section{Testicular biometry of Swiss albino mice}

The mean testicular length and weight obtained for both the left and right testes in mice across the groups were not significantly different $(p>0.05)$ except that there was a significant decrease $(p<0.05)$ in the mean testicular length of the right testes in the treatment groups (B, C, and D) compared to the control (Table 3). 
Table 1: Mean values for percentage motility, viability, volume and sperm count of Swiss albino mice in different groups.

\begin{tabular}{lcccc}
\hline Parameters & \multicolumn{4}{c}{ Groups } \\
\cline { 2 - 5 } & $\mathbf{A}$ & $\mathbf{B}$ & $\mathbf{C}$ & $\mathbf{D}$ \\
& $\mathbf{C o n t r o l}$ & $\mathbf{1 0 0 \%} \mathbf{W S F}$ & $\mathbf{1 0 \%} \mathbf{W S F}$ & $\mathbf{1 \%} \mathbf{W S F}$ \\
\hline Motility (\%) & $77.50 \pm 7.50^{\mathrm{a}}$ & $70.00 \pm 4.63^{\mathrm{a}}$ & $65.00 \pm 6.27^{\mathrm{a}}$ & $68.75 \pm 5.15^{\mathrm{a}}$ \\
Liveability (\%) & $96.50 \pm 0.87^{\mathrm{a}}$ & $94.88 \pm 1.51^{\mathrm{a}}$ & $94.25 \pm 1.62^{\mathrm{a}}$ & $96.50 \pm 0.57^{\mathrm{a}}$ \\
Volume (mls) & $5.18 \pm 0.03^{\mathrm{a}}$ & $5.16 \pm 0.02^{\mathrm{ab}}$ & $5.15 \pm 0.02^{\mathrm{b}}$ & $5.18 \pm 0.0^{\mathrm{a}}$ \\
Sperm count $\left(\mathrm{x} 10^{6}\right.$ sperm $\left./ \mathrm{ml}\right)$ & $126 \pm 3.92^{\mathrm{a}}$ & $119.75 \pm 3.47^{\mathrm{a}}$ & $105.88 \pm 8.73^{\mathrm{a}}$ & $109.63 \pm 7.0^{\mathrm{a}}$ \\
\hline \multicolumn{2}{l}{ Values are reported as mean $\pm \mathrm{SEM}$; $^{\text {a,ab }}$ Means with the same superscripts are not significantly different $(\mathrm{P}>0.05)$ along rows. }
\end{tabular}

Table 2: Mean values for spermatozoa morphology of Swiss albino mice in different treatment groups.

\begin{tabular}{lcccc}
\hline Parameters (\%) & \multicolumn{4}{c}{ Groups } \\
\cline { 2 - 5 } & Control & $\mathbf{1 0 0 \%} \mathbf{W S F}$ & $\mathbf{1 0 \%} \mathbf{W S F}$ & $\mathbf{1 \%} \mathbf{W S F}$ \\
\hline Tailless head & $1.37 \pm 0.07^{\mathrm{a}}$ & $1.4 \pm 0.07^{\mathrm{a}}$ & $1.34 \pm 0.07^{\mathrm{a}}$ & $1.3 \pm 0.06^{\mathrm{a}}$ \\
Headless tail & $1.06 \pm 0.06^{\mathrm{a}}$ & $1.06 \pm 0.11^{\mathrm{a}}$ & $1.12 \pm 0.08^{\mathrm{a}}$ & $1.18 \pm 0.08^{\mathrm{a}}$ \\
Rudimentary tail & $0.5 \pm 0.14^{\mathrm{a}}$ & $0.47 \pm 0.09^{\mathrm{b}}$ & $0.47 \pm 0.09^{\mathrm{ab}}$ & $0.43 \pm 0.08^{\mathrm{b}}$ \\
Bent tail & $1.99 \pm 0.10^{\mathrm{a}}$ & $2.24 \pm 0.16^{\mathrm{a}}$ & $2.27 \pm 0.14^{\mathrm{a}}$ & $2.26 \pm 0.15^{\mathrm{a}}$ \\
Curved tail & $2.06 \pm 0.0^{\mathrm{a}}$ & $2.21 \pm 0.10^{\mathrm{a}}$ & $2.08 \pm 0.05^{\mathrm{a}}$ & $2.17 \pm 0.06^{\mathrm{a}}$ \\
Curved mid-piece & $2.24 \pm 0.10^{\mathrm{a}}$ & $2.4 \pm 0.13^{\mathrm{a}}$ & $2.21 \pm 0.06^{\mathrm{a}}$ & $2.26 \pm 0.06^{\mathrm{a}}$ \\
Bent mid-piece & $2.06 \pm 0.12^{\mathrm{a}}$ & $2.18 \pm 0.11^{\mathrm{b}}$ & $2.12 \pm 0.07^{\mathrm{ab}}$ & $2.14 \pm 0.11^{\mathrm{b}}$ \\
Looped tail & $0.44 \pm 0.12^{\mathrm{a}}$ & $0.4 \pm 0.06^{\mathrm{ab}}$ & $0.43 \pm 0.08^{\mathrm{b}}$ & $0.46 \pm 0.0^{9}$ \\
Total abnormal & $11.71 \pm 0.22^{\mathrm{a}}$ & $12.35 \pm 0.60^{\mathrm{a}}$ & $12.04 \pm 0.18^{\mathrm{a}}$ & $12.210 .24^{\mathrm{a}}$ \\
Total normal & $389.54 \pm 1.22^{\mathrm{a}}$ & $389.53 \pm 1.23^{\mathrm{b}}$ & $389.84 \pm 0.89^{\mathrm{b}}$ & $390.91 \pm 1.21^{\mathrm{a}}$ \\
Total & $401.25 \pm 1.25^{\mathrm{a}}$ & $401.88 \pm 0.91^{\mathrm{a}}$ & $401.88 \pm 0.91^{\mathrm{a}}$ & $403.13 \pm 1.32^{\mathrm{a}}$ \\
\hline
\end{tabular}

Values are reported as mean $\pm S E M$

${ }^{a, b}$ Means with the same superscripts are not significantly different $(P>0.05)$ along rows.

Table 3: Testicular Biometry of Swiss Albino Mice in different treatment groups.

\begin{tabular}{lcccc}
\hline Parameters & \multicolumn{4}{c}{ Groups } \\
\cline { 2 - 5 } & Control & $\mathbf{1 0 0 \%}$ WSF & $\mathbf{1 0 \%}$ WSF & $\mathbf{1 \%}$ WSF \\
\hline Length of left testes (cm) & $0.88 \pm 0.04^{\mathrm{a}}$ & $0.90 \pm 0.02^{\mathrm{a}}$ & $0.85 \pm 0.03^{\mathrm{a}}$ & $0.82 \pm 0.03^{\mathrm{a}}$ \\
Length of right testes (cm) & $0.92 \pm 0.04^{\mathrm{a}}$ & $0.89 \pm 0.02^{\mathrm{b}}$ & $0.86 \pm 0.04^{\mathrm{ab}}$ & $0.84 \pm 0.03^{\mathrm{b}}$ \\
Weight of left testes $(\mathrm{mg})$ & $102.07 \pm 4.39^{\mathrm{a}}$ & $107.95 \pm 3.2^{\mathrm{a}}$ & $90.51 \pm 6.72^{\mathrm{a}}$ & $86.26 \pm 5.39^{\mathrm{a}}$ \\
Weight of right testes $(\mathrm{mg})$ & $105.78 \pm 4.57^{\mathrm{a}}$ & $99.2 \pm 4.42^{\mathrm{a}}$ & $96.58 \pm 5.49^{\mathrm{a}}$ & $86.15 \pm 6.49^{\mathrm{a}}$ \\
\hline
\end{tabular}

Values are reported as mean \pm SEM; ${ }^{a, b}$,Means with the same superscripts are not significantly different $(\mathrm{P}>0.05)$ along rows.

\section{DISCUSSION}

The semen characteristics observed in this study showed that there were no significant changes in the mean percentage sperm motility, livability score and sperm count across the groups, although the mean values obtained in the treatment groups $\mathrm{B}, \mathrm{C}$ and $\mathrm{D}$ were lower than the control but the values were still within the normal range for potential fertility in the mice. This suggests that the treatment had no adverse effect on the sperm cells of mice. This finding is in agreement with a report by Ochiogu et al. (2009) in which treatment with used engine 
lubricating oil had no negative effect on the fertility status of rat.

There was an increase in the total number of abnormal sperm cells in the treatment groups B, C and D compared to the control, although the changes were within the normal range proposed by Reece (1997). This is an indication that treatment with the water soluble fractions of spent engine oil at $1 \%$, $10 \%$ and $100 \%$ concentration had no negative effect on the spermatozoa morphology of mice. This is similar to the findings of earlier researchers in which decreased reproductive function of rats treated with used engine lubricating oil was attributed to its higher concentration of Lead, Magnesium, Potassium, Nickel, Silicon and Cadmium (Vasquez-Duhalt, 1989; CEPA, 1994; ATSDR, 1997, CEPA, 2002).

There was a significant reduction in the mean testicular length of the right testis of mice in the treatment groups compared to those in the control group. Also, there were reductions in the weight of testes of the mice the treatment groups compared to the control especially the right testes. This decreased testicular length and weight suggests both impaired secretory activities and impaired growth. This is similar to a study conducted by Orisakwe et al. (2003) in which male albino rats were treated with Nigerian bonny light crude oil. A similar pattern in testicular biometry has been shown after estrogen administration (Orgebin-Crist et al., 1983) and phenolic compounds like gossypol (Tso and Lee, 1982). However, in this study, the changes observed in other testicular parameters measured were not significant and this might be attributed to the slight disparity in the weights of the experimental mice.

\section{Conclusion}

Therefore, it was concluded in this study that treatment with water soluble fractions of spent engine oil for 30 days has no negative effect on the semen characteristics and testicular biometry of Swiss albino mice.

\section{COMPETING INTERESTS}

Authors have declared that no competing interests exist.

\section{AUTHORS' CONTRIBUTIONS}

This work was carried out in collaboration between all authors. AAO designed and supervised the study. OSA carried out the laboratory work, wrote, prepared and packaged the manuscript for publication. SOB carried out the experimental and field work. All authors read and approved the final manuscript.

\section{ACKNOWLEDGEMENTS}

The authors hereby acknowledge the Department of Veterinary Surgery and Reproduction, University of Ibadan for the access granted to use their Theriogenology Laboratory for this work.

\section{REFERENCES}

Agarry SE, Ogunleye OO. 2012. BoxBehnken design application to studyenhanced bioremediation of soil artificiallycontaminated with spent engine oil usingbiostimulation strategy. International Journal of Energy and Environmental Engineering, 3(31): 114.

Agbogidi OM, Eruotor PG. 2012. Morphological Changes Due to Spent Engine Oil Contamination and Its Heavy Metal Components of Jatropha curcas Linn Seedlings. International Conference on Bioscience, Biotechnology and Healthcare Sciences, pp.88-93.

Arise RO, Tella AC, Akintola AA, Akiode SO, Malomo SO. 2012. Toxicity Evaluation of Crankase Oil in Rats. EXCLI Journal, 11: 219-225.

ATSDR. 1997. Toxicological Profile of Used Mineral-Based Crankcase Oil. Agency for Toxic Substances and Disease Registry (ATSDR), Public Health Service, United States Department of 
Health and Human Services: Atlanta, Georgia, USA.

Breton J, Massart S, Vandamme P, De Brandt E, Pot B, Foligné B. 2013. Ecotoxicology inside the gut: impact of heavy metals on the mouse microbiome. BMC Pharmacology and Toxicology, 14(62).

CEPA. 1994. Waste Crankcase Oils - Priority Substances List Assessment Report. Canadian Environmental Protection Act (CEPA), Canada.

CEPA. 2002. Waste/Used Crankcase Oil Follow-up report on the PSLI substance for which there was insufficient information to conclude whether the substance constitutes a danger to the environment. Canadian Environmental Protection Act (CEPA), Canada.

Chukwuma SE, Ikechukwu NEO, Obinna AO. 2012. Comprehensive Perspectives in Bioremediation of Crude Oil Contaminated Environments. Introduction to Enhanced Oil Recovery (EOR) Processes and Bioremediation of Oil-Contaminated Sites. www.intechopen.com.

Deveci E, Deveci S. 2011. The effects of cadmium chloride on the oesophagus of rats. Int. J. Morphol., 29(3):678-680.

Ekeh FN, Ekechukwu NS, Atama CI., Atta, IC. 2010. Heamatological Profile of Albino Rats Given Feed and Water Contaminated with Varied Concentrations of Used Engine Oil. Animal Research International, 7(2): 1229-35. ISSN: $159-3115$

European Commission. 2002. Heavy Metals in Waste. Final Report.

Hu, H. 2002. Human health and heavy metals exposure. In Life Support, The Environment and Human Health, Michael McCally (ed). MIT Press.

Jihen EH, Imed M, Hamouda F, Abdelhamid K. 2008. Protective Effects of Selenium (Se) and Zinc (Zn) on Cadmium (Cd) Toxicity in the Liver and Kidney of the
Rat: Histology and Cd Accumulation. Food and Chemical Toxicology, 46: 3522-3527.

Kayode J, Oyedeji AA, Olowoyo O. 2009. Evaluation of the Effects of Pollution with Spent Lubricating Oil on the Physical and Chemical Properties of Soil. The Pacific Journal of Science and Technology, 10(1): 387-391.

Nagano M, Shimada H, Funakoshi T, Yasutake Y. 2000. Increase of Calcium Concentration in the Testes of Mice Treated with Rare Earth Metals. Journal of Health Science, 46(4): 314316.

Ochiogu IS, Ihedioha JI, Anya KO, Nwoye JCS. 2009. The reproductive performance of albino rats given drinking water contaminated with varied low percentages of used engine lubricating oil. Proceedings of the 34th Annual Conference of the Nigerian Society for Animal Production (NSAP), 34: 167-171.

Okonokhua BO, Ikhajiagbe B, Anoliefo GO, Emede TO. 2007. The Effects of Spent Engine Oil on Soil Properties and Growth of Maize (Zea mays L.). Journal of Applied Science Environmental Management, 11(3): $147-152$.

Olugboji OA, Ogunwole OA. 2008. Use of Spent Engine Oil. Australian Journal of Technology, 12(1): 67-71

Orgebin-Crust MC, Ellen BC, Danzo BJ. 1983. The effects of oestradiol, tamoxifen and testosterone on the weight and histology of the accessory sex organs of sexually immature rabbits. Endocrinology, 113: 17031715.

Orisakwe OE, Akumka DD, Njan AA, Afonne OJ. 2004. Testicular toxicity of Nigerian bonny crude oil in male albino rats. Reproductive Toxicology, 18: 439442.

Patrick-Iwuanyanwu K, Ogwe G, Onwuka F. 2009. The Hepatotoxic Effects of the Water-Soluble Fraction of Spent 
Lubricating Oil in Wistar Albino Rats. The Internet Journal of Toxicology, 7(2).

Reece WO. 1997. Physiology of Domestic Animals ( $2^{\text {nd }}$ edn). Williams and Wilkin: NY; 124-368.

Ssempebwa J, Carpenter D, Yilmaz B, DeCaprio A, O'Hehir D, Arcaro K. 2004. Waste crankcase oil: an environmental contami-nant with potential to modulate estrogenic responses. Journal of Toxicology and Environmental Health, 67: 1081-1094.

Tso WW, Lee CS. 1982. Lactate dehydrogenase-x, an isozyme particularly sensitive to gossypol inhibition. Int. J. Androl., 5: 205-209

Vasquez-Duhalt R. 1989. Environmental impact of used motor oil. The Science of the Total Environment., 79: 1-23.

Wang J, Jiq CR, Wong CK, Wong PK. 2000. Characterisation of polycyclic aromatic hydrocarbons created in lubricating oils. Water, Air and Soil Pollution, 120: 381-396.

Zemjamis, R. 1970. Diagnostic and Therapeutic Technique in Animal Reproduction ( $2^{\text {nd }}$ edn). Williams and Wilkins: NY; 139 -154. 